
Author(s): Lindroos, Jeanette \& Boulfrad, Yacine \& Yli-Koski, Marko \& Savin, Hele

Title:

\title{
Preventing light-induced degradation in multicrystalline silicon
}

Year: $\quad 2014$

Version: Final published version

\section{Please cite the original version:}

Lindroos, Jeanette \& Boulfrad, Yacine \& Yli-Koski, Marko \& Savin, Hele. 2014. Preventing light-induced degradation in multicrystalline silicon. Journal of Applied Physics. P. 5. 0021-8979 (printed). DOI: 10.1063/1.4871404.

Note:

Copyright 2014 American Institute of Physics. This article may be downloaded for personal use only. Any other use requires prior permission of the author and the American Institute of Physics.

http://scitation.aip.org/content/aip/journal/jap

All material supplied via Aaltodoc is protected by copyright and other intellectual property rights, and duplication or sale of all or part of any of the repository collections is not permitted, except that material may be duplicated by you for your research use or educational purposes in electronic or print form. You must obtain permission for any other use. Electronic or print copies may not be offered, whether for sale or otherwise to anyone who is not an authorised user. 


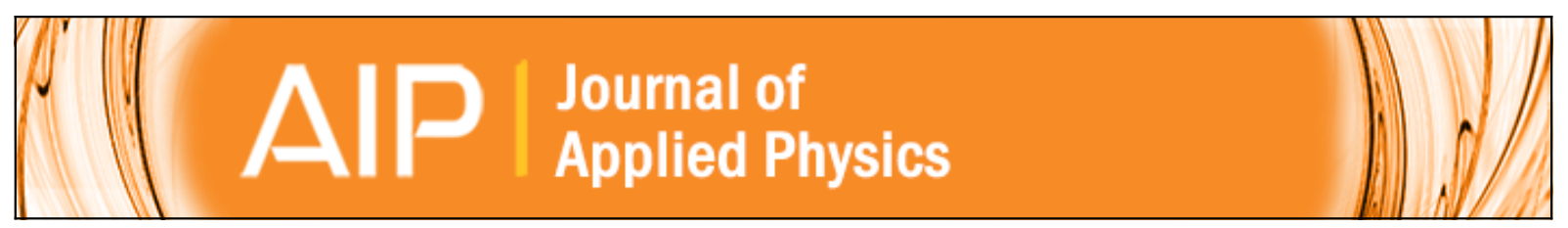

\section{Preventing light-induced degradation in multicrystalline silicon}

J. Lindroos, Y. Boulfrad, M. Yli-Koski, and H. Savin

Citation: Journal of Applied Physics 115, 154902 (2014); doi: 10.1063/1.4871404

View online: http://dx.doi.org/10.1063/1.4871404

View Table of Contents: http://scitation.aip.org/content/aip/journal/jap/115/15?ver=pdfcov

Published by the AIP Publishing

\section{Articles you may be interested in}

Experimental evidence on removing copper and light-induced degradation from silicon by negative charge Appl. Phys. Lett. 105, 182108 (2014); 10.1063/1.4901533

Room-temperature method for minimizing light-induced degradation in crystalline silicon

Appl. Phys. Lett. 101, 232108 (2012); 10.1063/1.4769809

Light-induced degradation in n-type Czochralski silicon by boron-doping and thermal donor compensation J. Appl. Phys. 112, 084509 (2012); 10.1063/1.4759245

Role of copper in light induced minority-carrier lifetime degradation of silicon

Appl. Phys. Lett. 95, 152111 (2009); 10.1063/1.3250161

Transition-metal profiles in a multicrystalline silicon ingot

J. Appl. Phys. 97, 033523 (2005); 10.1063/1.1845584

You don't

still use this

cell phone

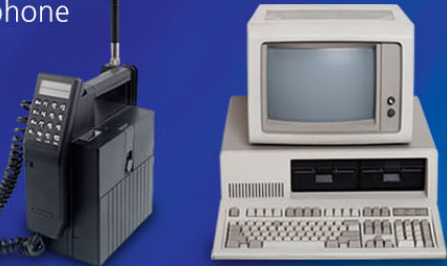

Why are you still using an AFM designed in the 80 's?
It is time to upgrade your AFM

Minimum $\$ 20,000$ trade-in discount for purchases before August 31st

Asylum Research is today's technology leader in AFM 


\title{
Preventing light-induced degradation in multicrystalline silicon
}

\author{
J. Lindroos, ${ }^{\text {a) }}$ Y. Boulfrad, M. Yli-Koski, and H. Savin \\ Department of Micro and Nanosciences, Aalto University, Tietotie 3, 02150 Espoo, Finland
}

(Received 21 January 2014; accepted 28 March 2014; published online 15 April 2014)

\begin{abstract}
Multicrystalline silicon (mc-Si) is currently dominating the silicon solar cell market due to low ingot costs, but its efficiency is limited by transition metals, extended defects, and light-induced degradation (LID). LID is traditionally associated with a boron-oxygen complex, but the origin of the degradation in the top of the commercial mc-Si brick is revealed to be interstitial copper. We demonstrate that both a large negative corona charge and an aluminum oxide thin film with a built-in negative charge decrease the interstitial copper concentration in the bulk, preventing LID in mc-Si. (C) 2014 AIP Publishing LLC. [http://dx.doi.org/10.1063/1.4871404]
\end{abstract}

\section{INTRODUCTION}

Light-induced degradation (LID) is a serious issue in crystalline silicon as one day of solar illumination decreases the absolute silicon solar cell efficiency by $1-2 \% .^{1}$ LID is most severe in low-resistivity Czochralski $(\mathrm{Cz})$ silicon, but degradation also occurs in multicrystalline silicon (mcSi). ${ }^{2-5}$ Even though LID has been studied extensively for nearly four decades, there is still no agreement on which minority carrier recombination center is responsible for LID in crystalline silicon. ${ }^{2,6}$ Most studies point to a highly recombination active boron-oxygen defect complex, ${ }^{7,8}$ but the defect composition and formation kinetics remain unclear. ${ }^{9}$ Although less is known about LID in $\mathrm{mc}-\mathrm{Si}$, the smaller degradation effect is regarded as a result of lower oxygen ${ }^{5}$ concentration and higher carbon ${ }^{10,11}$ concentration than in $\mathrm{Cz}$ $\mathrm{Si}$. Less degradation might also occur in mc-Si simply due to the lower initial minority carrier recombination lifetime $e^{3,4,10}$ caused by high levels of transition metals and high densities of extended defects such as stacking faults, grain boundaries, and dislocations.

Copper is a common $3 d$ transition metal impurity in silicon, which in its interstitial state has been observed to cause similar degradation in single crystalline silicon under illumination, ${ }^{12}$ even without the presence of boron ${ }^{13}$ or oxygen. ${ }^{14}$ Illumination of copper-contaminated silicon is proposed to enable the formation of recombination-active copper precipitates $\left(\mathrm{Cu}_{3} \mathrm{Si}\right),{ }^{15}$ and bulk microdefects ${ }^{14}$ are suggested to provide nucleation sites for copper precipitation. As mc-Si is well known to contain significant levels of copper impurities and extended defects, copper is likely to impact LID also in mc-Si. However, the effect of copper on LID in mc-Si is yet to be discovered.

Light-induced degradation has been reduced in $\mathrm{Cz}-\mathrm{Si}$ by applying a large negative corona charge onto an oxidized wafer. ${ }^{16,17}$ The negative corona charge is assumed to move interstitial $\mathrm{Cu}_{\mathrm{i}}^{+}$towards the wafer surface, ${ }^{18,19}$ reducing the copper bulk concentration and preventing precipitation during illumination. Even though a large negative corona charge reduces $\mathrm{LID}$ in $\mathrm{Cz}-\mathrm{Si}$, the same effect may not occur in mc$\mathrm{Si}$, since copper is thought to precipitate ${ }^{20,21}$ easily in mc-Si already prior to illumination. Since managing LID by

\footnotetext{
${ }^{\text {a)} E l e c t r o n i c ~ m a i l: ~ j e a n e t t e . l i n d r o o s @ a a l t o . f i ~}$
}

external corona charging may also not be feasible in solar cell manufacturing, other alternatives need to be investigated for replacing the external large negative corona charge. One such alternative is thin film aluminum oxide $\left(\mathrm{Al}_{2} \mathrm{O}_{3}\right)$, which provides good surface passivation in both single ${ }^{22}$ and multicrystalline ${ }^{23}$ p-type $\mathrm{Si}$ due to a low interface defect density $^{24}$ and a built-in negative charge. ${ }^{25}$ However, little is known about LID in $\mathrm{Al}_{2} \mathrm{O}_{3}$-passivated silicon.

Although a negative surface charge can be achieved by both corona charging and $\mathrm{Al}_{2} \mathrm{O}_{3}$ deposition, the two charge deposition methods clearly differ in charge formation mechanism and negative charge density. The negative corona charge is deposited at RT onto a high quality thermal oxide with low interface defect density, while the $\mathrm{Al}_{2} \mathrm{O}_{3}$ charge is formed in the poorer $\mathrm{Si} / \mathrm{Al}_{2} \mathrm{O}_{3}$ interface during a yet unknown ${ }^{25}$ process around $400^{\circ} \mathrm{C}$. In addition, mitigating LID in $\mathrm{Cz}-\mathrm{Si}$ requires a negative corona charge density $\sim 10^{13} \mathrm{~cm}^{-2}$ on an oxidized wafer, ${ }^{16}$ while typical $\mathrm{Al}_{2} \mathrm{O}_{3}$ charge densities amount to $\sim 10^{12} \mathrm{~cm}^{-2} \cdot 25$

In this article, we subject mc-Si wafers from different parts of the ingot to illumination in order to further understand the formation of LID in commercially available mc-Si. In addition, we deposit a large negative corona surface charge onto oxidized mc-Si to establish if interstitial copper can be moved towards the surface in mc-Si. Finally, we investigate the effect on LID of the negative built-in charge of $\mathrm{Al}_{2} \mathrm{O}_{3}$ and determine whether $\mathrm{Al}_{2} \mathrm{O}_{3}$ thin films can be used to mitigate degradation in $\mathrm{mc}-\mathrm{Si}$.

\section{EXPERIMENTAL}

\section{A. Sample preparation}

The experiments were performed on 190- $\mu$ m-thick sister wafers from the middle and top of a p-type multicrystalline silicon brick grown by the Directional Solidification method. Wafers near the bottom of the brick were also tested, but the minority carrier recombination lifetime was too low to reliably detect degradation. Table I details the wafer resistivity measured with an Eddy Current Probe, the interstitial oxygen $\left(\mathrm{O}_{\mathrm{i}}\right)$, and the substitutional carbon $\left(\mathrm{C}_{\mathrm{s}}\right)$ concentration measured with Fourier Transform Infrared Spectroscopy (FTIR) in the middle and top mc-Si wafers. Table I also presents the interstitial iron concentration obtained by measuring the 
TABLE I. Properties of multicrystalline silicon wafers.

\begin{tabular}{lcccc}
\hline \hline Position & $\begin{array}{c}\text { Resistivity } \\
(\Omega \mathrm{cm})\end{array}$ & $\begin{array}{c}{\left[\mathrm{O}_{\mathrm{i}}\right]} \\
\left(\mathrm{cm}^{-3}\right)\end{array}$ & $\begin{array}{c}{\left[\mathrm{C}_{\mathrm{s}}\right]} \\
\left(\mathrm{cm}^{-3}\right)\end{array}$ & $\begin{array}{c}{\left[\mathrm{Fe}_{\mathrm{i}}\right]} \\
\left(\mathrm{cm}^{-3}\right)\end{array}$ \\
\hline Top & $1.3-1.7$ & $(5.0-8.0) \times 10^{16}$ & $(2.0-5.5) \times 10^{17}$ & $3.2 \times 10^{11}$ \\
Middle & $1.8-2.0$ & $(0.9-1.1) \times 10^{17}$ & $(0.9-1.6) \times 10^{17}$ & $7.4 \times 10^{10}$ \\
\hline \hline
\end{tabular}

lifetime before and after iron-boron pair $(\mathrm{FeB})$ dissociation with Microwave Photoconductance Decay $\left(\mu\right.$-PCD). ${ }^{26}$

Each wafer was first cut into four $50-\mathrm{cm}^{2}$ samples for processing. The saw damage was etched in Hydrofluoric/ Nitric/Acetic acid, removing $20 \mu \mathrm{m}$ of sample thickness. All wafers were then cleaned for $10 \mathrm{~min}$ in a solution of $2 \% \mathrm{HF}$ and $0.5 \% \mathrm{HCl}$, in $\mathrm{SC} 1$ and again in fresh $2 \% \mathrm{HF}$ and $0.5 \%$ $\mathrm{HCl}$ solution. Next, a 16-nm thermal oxide was formed during $40 \mathrm{~min}$ of dry oxidation followed by $20 \mathrm{~min}$ of annealing at $900{ }^{\circ} \mathrm{C}$ in $\mathrm{N}_{2}$ atmosphere. The samples were then divided into three groups for further processing.

Group 1 middle and top samples were kept as oxidized reference samples, while group 2 samples were intentionally copper contaminated by spinning $2 \mathrm{ppm}(\mathrm{w} / \mathrm{v})$ of copper solution onto the sample front side. The copper contamination was subsequently diffused into the wafer bulk during a 20 min anneal at $800^{\circ} \mathrm{C}$ in $\mathrm{N}_{2}$ atmosphere. Finally, a corona charge was deposited onto both sides of the samples. A large negative charge $\left(-10 \mu \mathrm{C} / \mathrm{cm}^{2}\right.$ on the top wafers and $-12.8 \mu \mathrm{C} / \mathrm{cm}^{2}$ on the middle wafers) was used to drive $\mathrm{Cu}_{\mathrm{i}}^{+}$out of the wafer bulk, while a positive charge $(+4$ $\mu \mathrm{C} / \mathrm{cm}^{2}$ ) was deposited to keep $\mathrm{Cu}_{\mathrm{i}}^{+}$in the wafer bulk. Corresponding corona charges were also deposited onto the group 1 reference samples.

From the group 3 samples, the thermal oxide was first removed in $5 \% \mathrm{HF}$, after which the wafers were cleaned as before wafer oxidation. A 20-nm $\mathrm{Al}_{2} \mathrm{O}_{3}$ layer was then grown by thermal Atomic Layer Deposition (ALD) at $200^{\circ} \mathrm{C}$ using trimethylaluminum (TMA) and $\mathrm{O}_{3}$ as precursors. ${ }^{27}$ Finally, the $\mathrm{Al}_{2} \mathrm{O}_{3}$ passivation layer was activated by a 30 min anneal at $400^{\circ} \mathrm{C}$ in $\mathrm{N}_{2}$ atmosphere.

\section{B. Measurements}

Immediately after corona charge deposition or $\mathrm{Al}_{2} \mathrm{O}_{3}$ annealing, the initial minority carrier recombination lifetime was measured in all samples at medium injection level $\left(\sim 10^{14} \mathrm{~cm}^{-3}\right)$ with $\mu$-PCD. The deposited corona charge and the built-in $\mathrm{Al}_{2} \mathrm{O}_{3}$ charge were then allowed to impact the copper distribution in the dark at RT for at least $12 \mathrm{~h}$ before subjecting the samples to illumination. ${ }^{19}$ As no change lifetime change occurred during storage in the dark, copper diffusion prompted by the deposited surface charge did not significantly affect the surface recombination velocity in the $\mathrm{Si} / \mathrm{SiO}_{2}$ interface. Small areas $\left(1 \mathrm{~mm}^{2}\right)$ of good grains in sister samples were then illuminated with a bias light $(973.5 \mathrm{~nm})$. During illumination, the bias light intensity was decreased momentarily to measure the lifetime as a function of illumination time at a high injection level $\left(\sim 10^{16} \mathrm{~cm}^{-3}\right)$ with a pulsed $904 \mathrm{~nm}$ laser (200 ns). ${ }^{19}$

After illumination, the lifetime was again measured at medium injection with $\mu$-PCD. As high-intensity illumination dissociates FeB pairs, the lifetime measured during and immediately after illumination is not only affected by light-induced defect recombination but also by $\mathrm{Fe}_{\mathrm{i}}$ recombination. Therefore, the wafers were stored in dark for at least one day to restore $\mathrm{FeB}$ pairs. After storage in dark, the last lifetime value was measured at medium injection with $\mu$-PCD.

\section{RESULTS}

\section{A. LID as function of bias light intensity}

In $\mathrm{Cz}$-Si with copper contamination, illumination intensity affects the observed LID, as increasing the illumination intensity results in faster degradation. ${ }^{19}$ Nærland et $a .^{28}$ have also shown that increasing the illumination intensity increases the degraded area due to excess carrier diffusion. Figure 1 presents the high-injection level lifetime as a function of illumination time at intensities 1 and $18 \mathrm{~W} / \mathrm{cm}^{2}$ in an oxidized top mc-Si sample with positive corona charge $\left(+4 \mu \mathrm{C} / \mathrm{cm}^{2}\right)$, while Figure 2 shows the corresponding medium injection lifetime maps before and after illumination. High-light intensity illumination clearly accelerates degradation also in mc-Si, resulting in a larger degraded area. Fast degradation at high illumination intensity has been linked to copper precipitation in the bulk, preventing copper diffusion towards the samples surfaces. ${ }^{29}$ Therefore, all samples were illuminated at the high bias light intensity of $18 \mathrm{~W} / \mathrm{cm}^{2}$.

\section{B. LID after corona charge deposition}

The following lifetime measurements were performed in the same good grain area of oxidized mc-Si sister samples. Figure 3(a) presents the lifetime results in the middle reference samples (group 1) and the intentionally copper contaminated middle samples (group 2) with either positive or negative corona surface charge measured at medium injection level before and after illumination. Figure 3(b) displays the lifetime measured at high injection as a function of illumination time in the corresponding measurement points.

With positive surface charge $\left(+4 \mu \mathrm{C} / \mathrm{cm}^{2}\right)$, LID is observed in both the reference and the contaminated middle wafers, but the final degraded lifetimes differ remarkably. The degradation in the reference wafer corresponds to LID measured previously

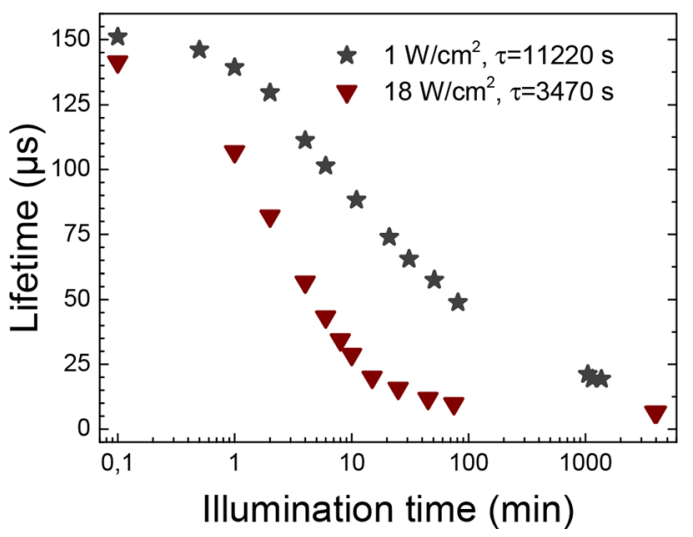

FIG. 1. Lifetime at high injection level as a function bias light illumination time at intensities 1 and $18 \mathrm{~W} / \mathrm{cm}^{2}$. 


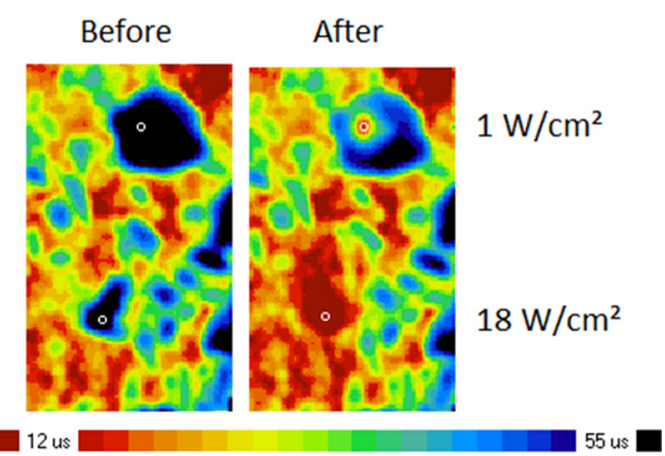

FIG. 2. Medium injection lifetime maps before (Before) and after (After) bias light illumination with intensities 1 and $18 \mathrm{~W} / \mathrm{cm}^{2}$. Illumination areas are marked by white circles.

in mc-Si at the corresponding oxygen level, ${ }^{4}$ while much faster and stronger LID is measured in the copper-contaminated wafer. As such, strong degradation has previously been measured in copper-contaminated $\mathrm{Cz}-\mathrm{Si}$, degradation in the contaminated mc-Si middle sample is most likely dominated by copper precipitation during illumination. ${ }^{14,16}$

Figure 4 presents the corresponding measurements in the reference (group 1) and the intentionally contaminated (group 2) top samples. With a positive corona charge, strong degradation is observed in the intentionally contaminated sample. In contrast to the middle of the brick, strong LID also appears in the top reference sample. Figure 4(b) shows that both the final degraded lifetimes and the degradation

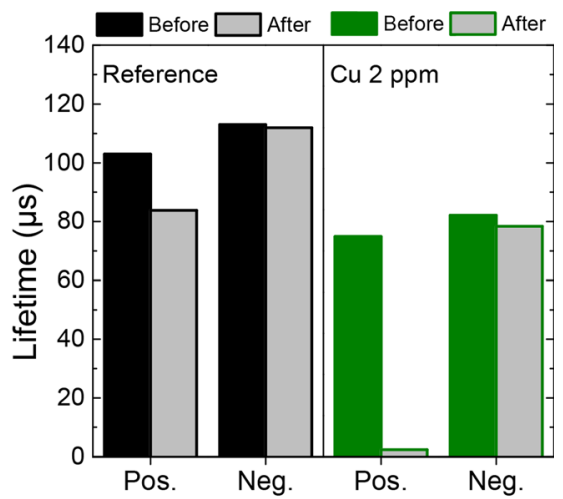

a)

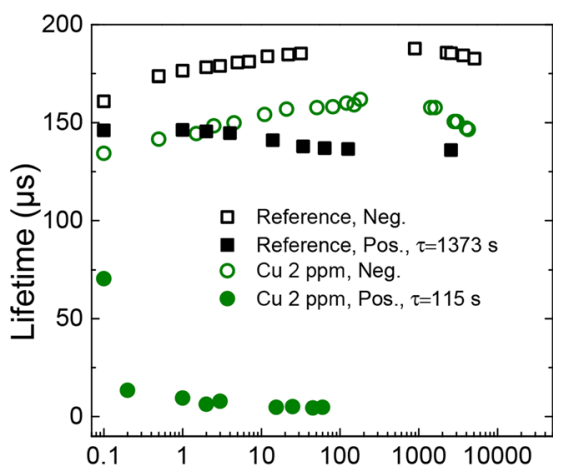

b) Illumination time ( $\mathrm{min}$ )

FIG. 3. Lifetime in a good grain point of oxidized middle wafers without (Reference) and with intentional copper contamination ( $\mathrm{Cu} 2 \mathrm{ppm}$ ) with surface charges $+4 \mu \mathrm{C} / \mathrm{cm}^{2}$ (Pos.) and $-12.8 \mu \mathrm{C} / \mathrm{cm}^{2}$ (Neg.) (a) measured at medium injection level before (Before) and after (After) illumination and (b) at high injection level as a function of illumination time.

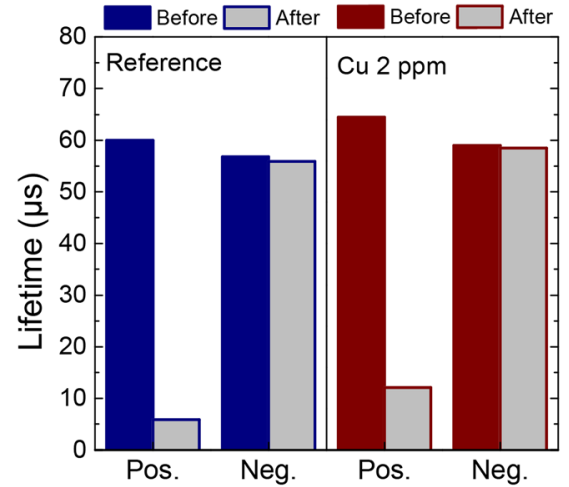

a)

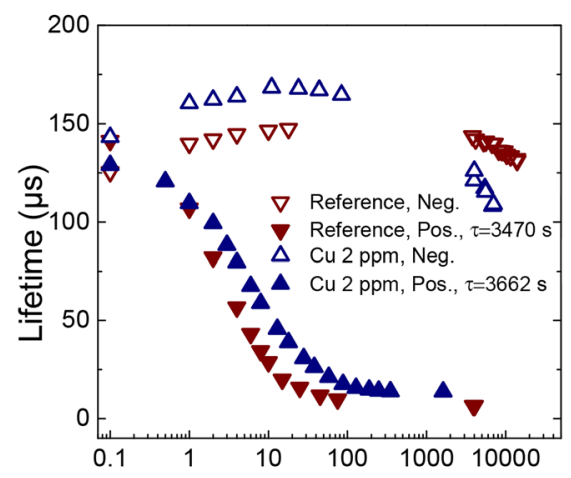

b) Illumination time ( $\mathrm{min})$

FIG. 4. Lifetime in a good grain point of oxidized top wafers without (Reference) and with intentional copper contamination (Cu $2 \mathrm{ppm}$ ) with surface charges $+4 \mu \mathrm{C} / \mathrm{cm}^{2}$ (Pos.) and $-10 \mu \mathrm{C} / \mathrm{cm}^{2}$ (Neg.) (a) measured at medium injection level before (Before) and after (After) illumination and (b) at high injection level as a function of bias illumination time.

rates are very similar in the reference and contaminated top samples. Thus, we can conclude that copper is most likely the origin of LID in the top of the commercial mc-Si brick.

The lifetime measured before and after degradation in Figs. 3 and 4 can be used to estimate the $\mathrm{Cu}_{\mathrm{i}}^{+}$concentration in the mc-Si samples, assuming that all degradation is caused by copper and that the illuminated grains contain a high micro defect density. ${ }^{30}$ This estimation results in a $\mathrm{Cu}_{i}^{+}$concentration of $(4.9 \pm 0.7) \times 10^{12} \mathrm{~cm}^{-3}$ in the top reference sample, which is similar to the estimated $(2.2 \pm 0.2) \times 10^{12} \mathrm{~cm}^{-3}$ in the contaminated top sample and $(6.8 \pm 1.4) \times 10^{12} \mathrm{~cm}^{-3}$ in the contaminated middle sample. The smaller degradation in the reference middle sample leads correspondingly to a clearly lower $\mathrm{Cu}_{i}^{+}$concentration estimate of $(1.7 \pm 0.2) \times 10^{10} \mathrm{~cm}^{-3}$.

Figures 3 and 4 also show the lifetimes measured in the middle and top samples with a large negative corona surface charge. After negative corona charge deposition, no LID is measured in any of the reference or intentionally contaminated samples. Despite the high bulk micro defect density in $\mathrm{mc}-\mathrm{Si}$, a large negative corona charge efficiently prevents LID in middle and the top of the mc-Si brick regardless of $\mathrm{Cu}_{\mathrm{i}}^{+}$concentration.

\section{LID after aluminum oxide passivation}

In addition to external corona charging, a negative surface charge can also be achieved by passivating the mc-Si samples 
with $\mathrm{Al}_{2} \mathrm{O}_{3}$ containing a negative built-in charge. Figure 5(a) presents the lifetime measured in a point of a good grain area of middle and top wafers with ALD-grown $\mathrm{Al}_{2} \mathrm{O}_{3}$ (group 3) before and after illumination. Figure 5(b) depicts the lifetime in the same measurement points at high injection level as a function of illumination time. As the $\mathrm{Al}_{2} \mathrm{O}_{3}$-passivated wafers were subjected to high-temperature oxidation prior to $\mathrm{Al}_{2} \mathrm{O}_{3}$ passivation, the wafers contain similar levels of interstitial copper as the oxidized reference wafers in Figs. 3 and 4. The charge density of the $\mathrm{Al}_{2} \mathrm{O}_{3}$ layer is estimated as $-7 \times 10^{12} \mathrm{~cm}^{-2}$, 27 while the surface charge density after corona charging can be calculated $-6.2 \times 10^{13} \mathrm{~cm}^{-2}$ on the oxidized top wafer.

During illumination in Fig. 5(b), the lifetime at high injection level stays stable in both middle and top wafers. At medium injection level, almost no degradation is measured in the top wafer at medium injection level, and only minor degradation is observed in the middle wafer in Fig. 5(a). Since a constant injection level between consecutive measurements can be guaranteed only in the high injection measurements, the stable lifetime behavior obtained in Fig. 5(b) represents the most reliable measurement data. Aluminum oxide thin film deposition is consequently successfully shown to prevent LID in mc-Si.

\section{DISCUSSION}

High total copper concentrations are expected in the top part of the mc-Si brick due to the strong segregation of copper to the melt during ingot solidification and high back diffusion

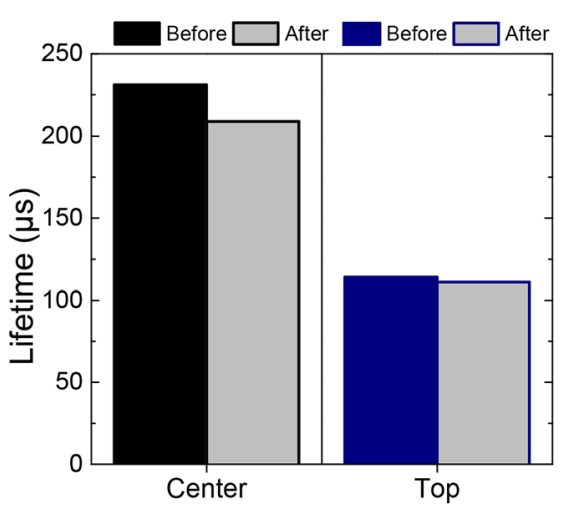

a)

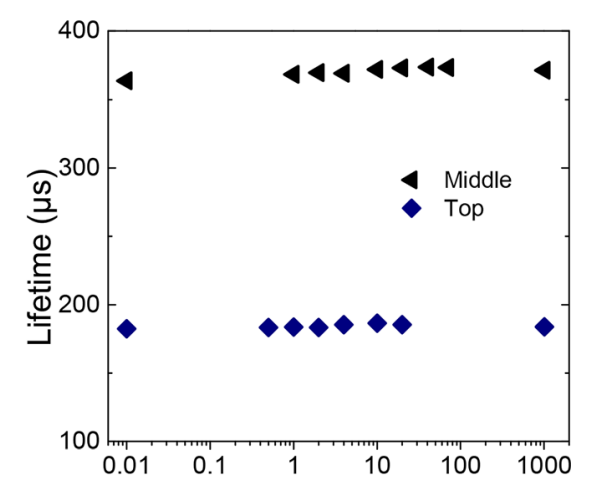

b) Illumination time ( $\mathrm{min}$ )

FIG. 5. Lifetime measured in a good grain point of a middle and top wafer with $\mathrm{Al}_{2} \mathrm{O}_{3}$ passivation (a) at medium injection level before (Before) and after (After) illumination and (b) at high injection level as a function of illumination time. during ingot cooling. ${ }^{31}$ However, a high interstitial copper concentration of $(4.9 \pm 0.7) \times 10^{12} \mathrm{~cm}^{-3}$ is surprising, considering the high extended defect density in the top of the brick and the lack of previous $\mathrm{Cu}_{i}^{+}$concentration data ${ }^{20,21,31,32}$ in $\mathrm{mc}-\mathrm{Si}$. Little is known about interstitial copper in $\mathrm{mc}-\mathrm{Si}$, since measuring the $\mathrm{Cu}_{i}^{+}$level in low-resistivity mc-Si grains is challenging with Transient Ion Drift (TID) ${ }^{33}$ due to the detection limit of $3 \times 10^{13} \mathrm{~cm}^{-3}$ and the need for accurate alignment of a 1-mm contact onto a homogeneous part of a mc-Si grain. As lifetime is very sensitive to copper precipitation, the lifetime measurements before and after illumination ${ }^{19}$ provide a valuable estimate for the $\mathrm{Cu}_{\mathrm{i}}^{+}$level in the mc-Si grain.

The high top interstitial copper concentration probably origins from copper precipitate dissolution during the hightemperature oxidation step. As the oxide built-in positive charge prevents copper out-diffusion to and precipitation at the sample surfaces during sample cooling, ${ }^{34}$ copper must stay in the sample bulk mostly as $\mathrm{Cu}_{i}^{+}$or $\mathrm{Cu}_{3} \mathrm{Si}$. In mc-Si, copper can precipitate homogeneously in the silicon lattice or heterogeneously at grain boundaries, stacking faults, and dislocations. ${ }^{35}$ Homogeneous precipitation requires a quasi-Fermi level above $\mathrm{E}_{\mathrm{c}}-0.2 \mathrm{eV},{ }^{36}$ which is not achieved at these copper levels ${ }^{15}$ during slow air cooling ${ }^{21}$ after oxidation or $\mathrm{Cu}$ in-diffusion. Therefore, copper is expected to precipitate heterogeneously at extended defects in mc-Si. ${ }^{20,21}$ However, our degradation results show that copper only partly precipitates during air cooling, leaving a significant concentration of $\mathrm{Cu}_{i}^{+}$in the oxidized mc-Si samples.

The $\mathrm{Al}_{2} \mathrm{O}_{3}$-passivated samples had been oxidized prior to $\mathrm{Al}_{2} \mathrm{O}_{3}$ deposition, to ensure significant levels of $\mathrm{Cu}_{\mathrm{i}}^{+}$in the samples. After ALD-growth of $\mathrm{Al}_{2} \mathrm{O}_{3}$, the effective lifetime improved in both top and middle samples occurred most probably by increased surface passivation, but also by bulk lifetime improvement due to further copper dissolution ${ }^{29}$ and $\mathrm{Cu}_{\mathrm{i}}^{+}$collection towards the surface during the $400{ }^{\circ} \mathrm{C}$ anneal. Employing only a low-temperature surface passivation method instead of oxidation could decrease the initial $\mathrm{Cu}_{\mathrm{i}}^{+}$concentration in the mc-Si samples. However, a negative surface charge would still need to be employed to prevent any lower level of $\mathrm{Cu}_{\mathrm{i}}^{+}$from precipitating during illumination.

Although both middle and top samples were intentionally contaminated with the same copper concentration in Figs. 3(b) and $4(\mathrm{~b})$, the degradation rate was much faster in the middle compared to the top. The difference in the degradation rate could be a result of the difference in bulk micro defect concentrations in the middle and the top of the brick. Oxygen and its related precipitates have been shown to increase the degradation rate in single crystalline silicon. ${ }^{19}$ Therefore, the slightly higher oxygen concentration in the middle sample probably caused a higher oxygen precipitate concentration, ${ }^{37}$ increasing the copper precipitation rate. Although dislocations and carbon may have enhanced oxygen precipitation in the top wafer, ${ }^{37}$ all degradation measurements were performed in good grains, reducing the probability of dislocation or carbon-induced oxygen precipitation in the top. In addition, the slower degradation rates in the top agree with previous studies reporting slower ${ }^{11}$ and less severe ${ }^{10}$ degradation in $\mathrm{mc}-\mathrm{Si}$ with high carbon concentrations. 


\section{CONCLUSION}

Commercial multicrystalline silicon wafers were thermally oxidized and subjected to illumination. In the top of the mc-Si brick, the minority carrier lifetime decreased from 141 to $7 \mu \mathrm{s}$ in a good grain area during illumination, which amounts to larger degradation than previously measured in mc-Si. A relatively high interstitial copper concentration of $(4.9 \pm 0.7) \times 10^{12} \mathrm{~cm}^{-3}$ was identified as the cause for the strong degradation. Such a $\mathrm{Cu}_{\mathrm{i}}^{+}$level was unexpected, as copper is thought to mainly exist as precipitates in $\mathrm{mc}-\mathrm{Si}$.

The measured LID was suppressed after the deposition of a large negative surface charge by either external corona charging or by atomic layer deposition of aluminum oxide. We suggest that the negative surface charge encouraged $\mathrm{Cu}_{i}^{+}$ diffusion towards the sample surfaces without causing significant precipitation at intra-grain defects during the outdiffusion. Interestingly, both negative charge deposition methods fully prevented the formation of recombinationactive copper precipitates during illumination, despite the differences in their charge densities and charge formation mechanism. In conclusion, $\mathrm{Al}_{2} \mathrm{O}_{3}$ deposition did not only increase the effective lifetime in silicon by improving surface passivation but also prevented light-induced degradation in $\mathrm{mc}-\mathrm{Si}$.

\section{ACKNOWLEDGMENTS}

This research was performed at the Micronova Nanofabrication Centre of Aalto University. The research leading to these results has received funding from the European Research Council under the European Union's Seventh Framework Programme (FP7/2007-2013)/ERC Grant Agreement No. 307315. J.L. acknowledges the support of the Finnish Cultural Foundation, Fortum Foundation, and Walter Ahlström Foundation.

${ }^{1}$ J. Schmidt, K. Bothe, and R. Hezel, in Proceedings of the 29th IEEE PVSC, New Orleans, LA, USA, 19-24 May (2002), pp. 178-181.

${ }^{2}$ K. Ramspeck, S. Zimmermann, H. Nagel, A. Metz, Y. Gassenbauer, B. Birkmann, and A. Seidl, in Proceedings of the 27th EU PVSEC, Frankfurt, Germany, 24-28 September (2012), pp. 861-865.

${ }^{3}$ H. Nagel, J. Schmidt, A. G. Aberle, and R. Hezel, in Proceedings of the 14th EU PVSEC, Barcelona, Spain, June 30-July 4 (1997), pp. 762-765.

${ }^{4}$ D. H. Macdonald, L. J. Geerligs, and S. Riepe, in 13th Workshop on Crystalline Silicon Solar Cell Materials and Processes, Vail, Colorado, USA (2003), pp. 182-185.

${ }^{5}$ J. Junge, A. Herguth, G. Hahn, D. Kre $\beta$ ner-Kiel, and R. Zierer, Energy Procedia 8, 52-57 (2011).

${ }^{6}$ A. R. Peaker, V. P. Markevich, B. Hamilton, G. Parada, A. Dudas, A. Pap, E. Don, B. Lim, J. Schmidt, L. Yu, Y. Yoon, and G. Rozgonyi, Phys. Status Solidi A 209, 1884-1893 (2012).

${ }^{7}$ J. Schmidt, A. G. Aberle, and R. Hezel, in Proceedings 26th IEEE PVSC, Anaheim, CA, USA, September 30-October 3 (1997), pp. 13-18.

${ }^{8}$ S. W. Glunz, S. Rein, W. Warta, J. Knobloch, and W. Wettling, Sol. Energy Mater. Sol. Cells 65, 219-229 (2001).
${ }^{9}$ V. V. Voronkov and R. Falster, Solid State Phenom. 205-206, 3-14 (2013).

${ }^{10} \mathrm{G}$. Coletti, C. L. Mulder, G. Galbiati, and L. J. Geerligs, in Proceedings of the 21st EU PVSEC, Dresden, Germany, 4-8 September (2006), pp. $1515-1518$.

${ }^{11}$ S. Dubois, N. Enjalbert, J. Veirman, J. P. Garandet, F. Tanay, A. Jouini, and J. Champliaud, in Proceedings of 6th International Workshop on Science and Technology of Crystalline Silicon Solar Cells, Aix-les-Bains, France, 8-11 October (2012).

${ }^{12}$ D. Ramappa, Appl. Phys. Lett. 76, 3756 (2000).

${ }^{13}$ J. Lindroos, M. Yli-Koski, A. Haarahiltunen, M. C. Schubert, and H. Savin, Phys. Status Solidi (RRL) 7, 262-264 (2013).

${ }^{14}$ H. Savin, M. Yli-Koski, and A. Haarahiltunen, Appl. Phys. Lett. 95, 152111 (2009).

${ }^{15}$ R. Sachdeva, A. A. Istratov, and E. R. Weber, Appl. Phys. Lett. 79, 2937 (2001).

${ }^{16}$ J. Lindroos, M. Yli-Koski, A. Haarahiltunen, and H. Savin, Appl. Phys. Lett. 101, 232108 (2012).

${ }^{17}$ Y. Boulfrad, J. Lindroos, A. Inglese, M. Yli-Koski, and H. Savin, Energy Proc. 38, 531-535 (2013).

${ }^{18}$ Y. Kitagawara, H. Takeno, S. Tobe, Y. Hayamizu, T. Koide, and T. Takenaka, in Mater. Res. Soc. Symp. Proc. Vol. 510, San Francisco, CA, USA, 13-17 April, 1998, edited by S. Ashok, J. Chevallier, W. Goetz, B. L. Sopori, and K. Sumino (Materials Research Society, 1998), pp. 3-14.

${ }^{19}$ H. Väinölä, M. Yli-Koski, A. Haarahiltunen, and J. Sinkkonen, J. Electrochem. Soc. 150, G790-G794 (2003).

${ }^{20}$ A. A. Istratov, T. Buonassisi, R. J. McDonald, A. R. Smith, R. Schindler, J. A. Rand, J. P. Kalejs, and E. R. Weber, J. Appl. Phys. 94, 6552-6559 (2003).

${ }^{21}$ X.-Q. Li, D.-R. Yang, X.-G. Yu, and D.-L. Que, Trans. Nonferrous. Met. Soc. 21, 691-696 (2011).

${ }^{22}$ B. Hoex, J. J. H. Gielis, M. C. M. van de Sanden, and W. M. M. Kessels, J. Appl. Phys. 104, 113703 (2008).

${ }^{23}$ P. Repo, H. Talvitie, S. Li, J. Skarp, and H. Savin, Energy Proc. 8, 681-687 (2011).

${ }^{24}$ R. Hezel and K. Jaeger, J. Electrochem. Soc. 136, 518-523 (1989).

${ }^{25}$ G. Dingemans and W. M. M. Kessels, J. Vac. Sci. Technol., A 30, 040802 (2012).

${ }^{26}$ A. Haarahiltunen, H. Väinölä, M. Yli-Koski, E. Saarnilehto, and J. Sinkkonen, in High Purity Silicon VIII: Proceedings of the International Symposium, Honolulu, HI, USA, 3-8 October 2004, edited by C. L. Claeys, M. Watanbe, R. Falster, and P. Stallhofer (The Electrochemical Society, 2004), pp. 135-145.

${ }^{27}$ G. von Gastrow, S. Li, P. Repo, Y. Bao, M. Putkonen, and H. Savin, Energy Proc. 38, 890-894 (2013).

${ }^{28}$ T. U. Nærland, H. Angelskår, and E. Stensrud Marstein, J. Appl. Phys. 113, 193707 (2013).

${ }^{29}$ A. Belayachi, T. Heiser, J. P. Schunk, and A. Kempf, Appl. Phys. A 80, 201-204 (2005)

${ }^{30}$ H. Väinölä, E. Saarnilehto, M. Yli-Koski, A. Haarahiltunen, J. Sinkkonen, G. Berenyi, and T. Pavelka, Appl. Phys. Lett. 87, 032109 (2005).

${ }^{31}$ D. Macdonald, A. Cuevas, A. Kinomura, Y. Nakano, and L. J. Geerligs, J. Appl. Phys. 97, 033523 (2005).

${ }^{32}$ M. B. Shabani, T. Yamashita, and E. Morita, ECS Trans. 16(6), 179-193 (2008).

${ }^{33}$ T. Heiser and A. Mesli, Appl. Phys. A 57, 325-328 (1993).

${ }^{34}$ M. B. Shabani, T. Yoshimi, and H. Abe, J. Electrochem. Soc. 143, 2025-2029 (1996).

${ }^{35}$ A. A. Istratov and E. R. Weber, Appl. Phys. A 66, 123-136 (1998).

${ }^{36}$ A. A. Istratov, H. Hedemann, M. Seibt, O. F. Vyvenko, W. Schröter, T. Heiser, C. Flink, H. Heislmair, and E. R. Weber, J. Electrochem. Soc. 145, 3889-3898 (1998).

${ }^{37}$ H. J. Möller, L. Long, M. Werner, and D. Yang, Phys. Status Solidi A 171, 175-189 (1999). 